FACTA UNIVERSITATIS

Series: Economics and Organization Vol. 15, No 1,2018 , pp. 1 - 13

https://doi.org/10.22190/FUEO1801001D

Original Scientific Paper

\title{
CIVIC AND POLITICAL PARTICIPATION IN TRANSITION COUNTRIES: THE CASE OF SERBIA
}

UDC 347.471:329(497.11)

\section{Marija Džunić, Nataša Golubović}

University of Niš, Faculty of Economics, Niš, Serbia

\begin{abstract}
The purpose of this paper is to explore the dynamics of civic participation in Serbia, as well as to test its relevance for the level of citizens' political involvement. For estimating the impact of the membership in civic associations on political party membership and non-conventional types of political activism, the non-parametric analyses of variance test, followed by post hoc testing has been employed. The main findings of the analysis suggest that civic participation is a significant predictor of political activism of Serbian citizens. The results of the empirical procedures indicate significant differences in the degree of political participation, based on the levels of citizens' engagement in community organizations. The implications of the study could serve as the grounds for designing policies aimed at strengthening civic society and creating incentives for citizens' active involvement in political life.
\end{abstract}

Key words: civic society, political participation, transition, democracy

JEL Classification: P26, D71

\section{INTRODUCTION}

Civic society represents a part of the public space between the family and the state (Morje, 2003), essential for the credibility of institutions and articulation of citizens' demands, as well as a mechanism which provides accountability of politicians. Low levels of electoral turnout, lack of trust in political institutions and declining levels of civic engagement are perceived as a serious sign of the erosion of democracy.

For transition countries, that have implemented extensive political and economic changes in the last few decades, civic participation is of essential importance. This region has put much effort on reforming formal institutions, while the informal dimension of

Received November 07, 2017 / Accepted December 11, 2017

Corresponding author: Marija Džunić

University of Niš, Faculty of Economics, Trg kralja Aleksandra 11, 18000 Niš, Serbia

E-mail: marija_dzunic@ni.ac.rs 
democratic consolidation had received much less attention. The first phase of the transition from non-democratic to democratic regimes in Central and Eastern Europe consisted of liberalization and the demise of authoritarian system, followed by democratization and social modernization. After the institutional base of a democratic system was created, the next necessary step was democratic consolidation, as the final step in the transformation process, in order to embed democratic values and practices into the citizens' political culture. The gap between formal and substantive democracy in Central and Eastern Europe is often explained as the result of the legacy of authoritarianism and the weakness of democratic institutions.

There is a rising concern regarding the quality and magnitude of citizen participation throughout the transition countries. Numerous research studies imply that civic participation in these countries is low compared to the level recorded in Western Europe and North America. The weakness of civic society and low levels of citizens' participation has often been linked to low levels of social capital and the legacy of centrally-planned economy. At the beginning of the transition, it was expected that reforms will lead to the increase of civic engagement. Instead, many authors claim that we are dealing with the civic demobilization, and that civil society which initiated extensive political and economic changes at the beginning of the transition is on the downward path. The assumptions regarding passive civil society and political apathy throughout the region and the hypothesis about weakness of post-communist civil society have not been conclusively confirmed. Also, despite common communist legacy, there are significant differences in the development of civic society in different countries during transition so that the post-communist civil society could not be referred to as a singular phenomenon.

This paper explores the dynamics of civic and political participation in Serbia in the aftermath of the transition reforms. Patterns of political participation will be studied in relation to the intensity of civic engagement in order to establish the relevance of civic participation for explaining citizens' involvement in political activities, and consequently, its role in fostering democratic consolidation.

\section{LITERATURE REVIEW}

Over the last decades, there is a growing academic interest for the economic analysis of civic engagement. The 2009 Nobel Prize for Economics, granted to Elinor Ostrom, rewarded research on civic participation. Ostrom (1990) argues that common pool resources can be governed sustainably in a community. Although relatively new in economics, the analysis of civic participation has for a long time occupied the attention of scholars in the social sciences. Referring to his journey across the United States during 1831, Alexis de Tocqueville described in detail the richness of civil associations that support American democracy and economic power (de Tocqueville, 1835, 1840 [1990]). Interactions within voluntary associations are a kind of, as he puts it - "social glue" - that connects Americans, as opposed to formal relations which are based on traditional and hierarchical relationships which have been observed in Europe. Some sixty years later, the French sociologist Emil Durkheim dealt with social relationships as a source of social order (Durkheim, 1984 [1893]).

It seems that rising interest in this field in the last few decades is caused by declining electoral turnout, lack of trust in political institutions and declining levels of civic 
engagement (Putnam, 2000). Putnam was among the first authors to express concerns about the decline of civic engagement. According to Putnam, one of the factors that causes differences in the efficiency of local governments and regional economic performances in Italy are differences in social structures. Part of the economic success of Northern Italy (compared to the southern part of the country) is related to civic associations, which instill in their members a sense of cooperation, solidarity and general interest (Putnam, 1993, p. 89-90). Effective governance draws (relies) on the tradition of civic engagement and civic networks. In the regions characterized by dense horizontal social relations, based on trust and common values, participation in voluntary organizations and associations is more intensive and social capital is highly developed. Regions with successful government and efficient economy are characterized by horizontal relationships that foster and encourage civic engagement. Putnam considers that any form of civic engagement is beneficial for society and tends to correlate with a functioning democracy and market economy (Putnam, 1993). The key problem is that virtually all forms of political and social engagement are on the verge of decline in the USA since 1940s, meaning that American democracy is eroding from the inside (Putnam, 1995; 2000). Similar concerns were expressed in a number of different studies, where the decline of participation in social and political activities through traditional channels has been established (Skocpol \& Fiorina, 1999; Norris, 1999). It has been argued that the decline in participation could lead to the erosion of democracy (Kaase \& Newton, 1995; Norris, 2002). Putnam's work sparked a wide debate about the future of democracy, but the key problem with this argument is that Putnam never established a precise definition of civic engagement (Adler \& Goggin, 2005). His understanding of civic participation includes a wide range of formal and informal activities, from reading newspapers, interpersonal trust, associational involvement to various forms of political participation. A number of such heterogeneous activities are placed under the umbrella of social capital. According to some authors (Berger, 2009, p. 336; Sartori, 1970), civic engagement is a typical example of conceptual stretching, i.e. concept that comprises a bit of everything.

It is not universally accepted that a decline in civic participation levels is the same thing as the erosion of democracy. Also, there is a strong dispute about whether we are dealing with the decline of civic engagement at all (Norris, 2002, pp. 5-7; Stolle \& Hooghe, 2005; Berger, 2009). The evidence of a decline in civic participation is still rather inconclusive. Verba et al. (1995, p. 71) find that some forms of political activity increased from 1967 to 1987 (persuading others to vote, working for candidates, contributing money to candidates and parties; and contacting public officials). Rosenstone and Hansen (1993, ch. 3) found no clear trend in the activities such as working for parties or candidates and in signing petitions, but found strong increases in campaign contributions. Using data from the Roper Social and Political Trend data set from 1974 to 1994, Uslaner (2005) presented evidence of a consistent decline of political participation. For each of the investigated political activities (contacting public officials, attending rallies and public meetings, running for office, organizing and serving as an officer on committees, writing letters or articles for the press, working for a party, giving a speech, and being a member of a political club) there has been a decline in participation over time. However, Uslaner did not find indisputable evidence for the decline of other forms of civic engagement. One plausible explanation is that although membership in the traditional civic groups has experienced a decline, in the meantime many new forms of civic organizations emerged that may have replaced old style civic groups that were popular in the time of Putnam's research (Wuthnow, 1998). General 
Social Survey data (GSS) show that decreases in membership has been registered for only four groups out of 15: religious and church, labour and fraternal organizations. Membership in other groups either remained unchanged or has actually increased (professional associations). Uslaner (2005) claims that there are many different forms of participation which have different roots (meaning that what works to get people involved in one arena often has little effect in another) which explains why some forms of participation have declined, others have risen, and some have remained flat. Uslaner classifies the long list of social and political activities into three dimensions: political involvement, religious participation and community engagement. He found that these dimensions are largely mutually independent. Although community engagement is correlated with both religious and political activities, these correlations are far from strong. What stands out particularly from his analysis is that group memberships are unrelated to any other form of participation. It means that a community involvement does not mean that a person is more or less likely to take part in political activities. Some people are engaged in religious activities, some are politically active and other are prone to take part in communal activities.

Transition countries have implemented extensive political and economic reforms during the past few decades. Prior to transition, a long history of repression discouraged people from broadly associating with others, which has led to political apathy among citizens of those countries. There were very few civic organizations, and those that existed were in the service of the state, and they were mainly concentrated in the areas of sports and culture (Rose-Ackerman, 2001). Trade unions and professional associations are organizations whose existence has been allowed, but without a significant social impact. Just before the start of the transition, in some countries independent organizations have begun to emerge and from the last decade of the previous century, most of them began to gain autonomy and their own identity. Over time, more or less forced participation was gradually replaced by voluntary activities. Relatively stronger emphasis on sports and culture, as well as on professional associations and trade unions that existed in the previous system, apparently was kept during the transition, and the development of other organizations was heavily dependent on financial support. The beginning of the transition period was marked by the significant rise of civic initiative, expressed through officially registered organisations. Rapid development was followed by the slowing-down of civil society growth since the mid-1990s, that is, consolidation of civil society, further development and strengthening of existing organization and to a much lesser extent establishment of new ones.

Scholars from different disciplines warn us that civil society is structurally deficient in post-communist countries, since new democracies did not manage to develop and strengthen civic initiatives and participation in governance (Lomax, 1997; Ely, 1994). These countries are characterized by the low level of interpersonal and institutional trust and associational activity (Wallace et al., 2012). Since civic and political participation are crucial for the consolidation of new democracies in the region (Badescu \& Radu, 2010), the rising popularity of radical right parties in Central and East European countries has been perceived as a natural outcome of the low level of civic engagement (Rupnik, 2007; Minkenberg, 2002).

Majority of debates about civic participation in transition countries are rooted in Marc Morje Howard's 'weakness of civil society' hypothesis. According to this hypothesis, citizens in these countries exhibit lower levels of civic and political engagement compared to other democracies. Howard points out to the existence of closed networks based on family ties and a lack of trust towards people outside of those networks. This is 
the so called bonding social capital and these societies did not manage do develop bridging social capital, which is very important for the development of interpersonal trust. In addition, Howard points out to the legacy of distrust towards communist organisations and disappointment with post-communist politics (Howard, 2002; 2003).

Participation in voluntary associations has not been encouraged in former socialist countries. Autocratic control resulted in low levels of interpersonal trust, which became a permanent characteristic of post-socialist societies (Inglehart, 1999; Rose, 2009). Low level of interpersonal trust discouraged citizens to take risks that are necessary for social change, which is perceived as a sign that political culture in former socialist countries is subjective and passive. Petričušić (2013) points out to the legacy of social and political distrust, resulting in a greater prominence of informal, rather than formal or associational type of networks. Countries with low levels of interpersonal trust are less likely to build the kind of vibrant civil society that spurs strong government performance, and the result is low citizen confidence in government and public institutions (Newton \& Norris, 2000).

There is a disagreement among scholars about whether civil society in the region should be considered as vibrant or vulnerable. Not everybody agrees with the claim that the level of civic engagement in the post-communist countries is low. Since there was seemingly very mobilized and active civil society at the beginning of transition, which gave rise to development of democracy, civil and political rights and freedom, we should expect vibrant civic activity, instead of civic passivity. Ekiert and Foa (2011) suggest that the argument about passive civil society and political apathy throughout the region is not true, and that the argument about the weakness of post-communist civil society has not been empirically confirmed.

\section{DATA OVERVIEW AND METHODOLOGY}

The data used in this study is obtained from the European Bank for Reconstruction and Development (hereafter EBRD) survey of households and individuals across the transition region - the Life in Transition Survey (EBRD, 2016). This survey provides data on individual views of citizens on democracy, market economy and the impact transition reforms have had on their lives. The survey aims to explore life satisfaction and expectations regarding the future, interviewing over 51000 households in 29 transition countries. In our empirical estimations, data from the most recent round of the survey (LiTS, 2016), carried out in over 1500 households in Serbia during the year of 2016, will be used, along with data collected in previous rounds of the survey (LiTS, 2006; LiTS, 2010) for the purpose of comparisons.

To estimate the relevance of civic engagement in voluntary associations on political involvement in Serbia, we perform a non-parametric analyses of variance test, the Kruskal-Wallis H test (Kruskal and Wallis 1952). This procedure is used for testing the assumption that the intensity of political participation differs based on the level of participation in community associations. In other words, we test whether there are significant differences in multiple forms of political participation between groups characterized by different degrees of civic activism (active membership, non-active membership and not being a member). As the test confirms the presence of significant differences, we employ post hoc tests to determine which specific groups differ significantly among each other.

The variable approximating civic participation used in our analysis is the membership in voluntary organisations. This quantitative measure estimates the intensity of civic 
engagement by counting the respondents engaged in various types of community organisations. This measure allows for the differentiation of the degrees of activism, since it indicates the extent to which respondents are active in civic associations (as active, passive, or non-members). Following the majority of studies in this area, we explore the extent of participation in a wide range of associations and groups as the main indicator of citizens' participation in the social life.

The dynamics of political participation is captured by data on conventional participation in terms of political party membership, but also on self-reporting participation in three forms of non-conventional political activities, such as attending demonstrations, participating in strikes and signing petitions. Since political participation is a more complex phenomenon that includes not only voting behaviour, but also demonstrations, strikes, boycotts and other forms through which citizens can influence politics, political participation nowadays is usually understood as a range of voluntary activities by citizens, with the aim to influence political choices at various levels of the political system (Milbrath, Goel 1977, 2; Kaase, Marsch 1979, 42). These measures of political involvement are frequently used in empirical studies of political participation, as most reliable indicators of political involvement, closely related to the mechanisms of political representation. Representing more demanding and active forms of political participation, the indicated variables indirectly reflect the quality of democratic system.

Table 1 Levels of civic participation in Serbia (\% of total respondents)

\begin{tabular}{lrrrrrr}
\hline \multirow{2}{*}{ Community organizations } & \multicolumn{3}{c}{ Active member } & \multicolumn{2}{c}{ Inactive member } & \multicolumn{2}{c}{ Not a member } \\
\cline { 2 - 7 } & 2010 & 2016 & 2010 & 2016 & 2010 & 2016 \\
\hline Religious & 3,82 & 7,89 & 24,29 & 12,93 & 71,89 & 79,18 \\
Sports and recreational & 3,69 & 3,38 & 2,70 & 7,49 & 93,61 & 89,12 \\
Art music or educational & 2,63 & 2,06 & 1,18 & 4,58 & 96,18 & 93,37 \\
Labour unions & 2,96 & 1,92 & 5,01 & 7,10 & 92,03 & 90,98 \\
Environment & 0,53 & 0,53 & 1,05 & 3,85 & 98,42 & 95,62 \\
Professional & 2,37 & 2,59 & 1,78 & 4,05 & 95,85 & 93,37 \\
Humanitarian or charitable & 1,78 & 1,13 & 1,78 & 6,23 & 96,45 & 92,64 \\
Youth & 0,66 & 0,73 & 0,59 & 1,99 & 98,75 & 97,28 \\
Women's groups & $/$ & 0,66 & $/$ & 2,65 & $/$ & 96,68 \\
Farming cooperatives & $/$ & 0,80 & $/$ & 2,06 & $/$ & 97,15 \\
\hline
\end{tabular}

Source: LiTS, 2010; $2016^{2}$

To explore the patterns of civic participation in Serbia, Table 1 reports the percentages of active, inactive and non-members in a number of voluntary organizations.

The findings indicate that a majority of Serbian citizens refrain from participating in formal community organizations. Over $65 \%$ of all respondents do not belong to any of them, $17,6 \%$ report membership (active or inactive) in one organization, 7,5\% claim to participate in two community organizations, while $9 \%$ of the respondents participate in 3 or more associations (not enclosed in table, author's calculations based on LiTS, 2016). Narrowing the concept of civic participation to active membership in community organizations indicates that only $10 \%$ of citizens are actively engaged in one organization, while the minority of citizens (around 5\%) are active in two or more associations.

${ }^{2}$ Comparable data on membership in voluntary organizations are available only in the second and third round of the LiTS. 
Comparing the degree of associational activity with countries belonging to the developed world, Western Europe or North America, the findings suggest that civic participation in Serbia is hardly prevalent, measured by formal group membership.

There is a lively debate on which types of community engagement seem to be relevant for political pluralism and democratic consolidation, resulting in a wide list of heterogeneous organizations that are supposed to affect citizenry competence and political involvement in different ways. The assumption is that membership in various organizations, even if not being considered politically relevant or involving active participation, does improve civic competence and efficacy (Almond and Verba, 1963). The distribution of membership across different types of civic organizations indicates that among the minority of citizens that join community groups, the most popular organizations are church, sports associations and labour unions. The interest in vocational associations, such as professional or arts, music and educational groups is somewhat lower. Least popular civic associations are those belonging to third sector (humanitarian organizations, groups protecting women rights, youth cooperatives, environmental associations). The citizens of Serbia appear to be reluctant to join the associations that capture the original notion of civic society (such as organizations of the non-profit sector), while being more apt to participate in business and life-style associations and work force related organizations.

The dynamics of civic participation in Serbia in the post-transition period does not support the assumption of discouraged citizen engagement. Compared to the findings of the first round of the survey (LiTS, 2006), where only around 7\% of the respondents reported to be members of a civic/voluntary organization (club, association), ten years later over $35 \%$ of citizens are actively or passively engaged in one of the many types of civic associations. Furthermore, in the last five years, the degree of civic participation has increased in all types of associations, except for the church. However, a closer look into the pattern of participation in the majority of organizations reveals that, although the total membership has indeed increased since the last measurement, the increase has largely concerned the passive forms of participation. Active participation has only improved in professional and youth organizations.

Tables 2 and 3 report on data concerning forms of political participation in Serbia in the last decade. The proportion of respondents that are members of political parties is $8,5 \%$. This contrasts sharply from, for example, Germany, as an established democracy, where selfreported party membership mounts up to $13,6 \%$, but also from Italy, where party membership is only $3,3 \%$. These facts imply that even established democracies are highly differentiated in terms of party membership, so the value of this indicator does not make Serbia a special case. However, the data clearly indicate a slight political disengagement of citizens, measured in terms of membership, as a conventional form of participation.

On the other hand, the dynamics of political participation in terms of non-conventional political activities seems to follow the pattern observed in civic participation. Namely, the proportion of citizens that express reluctance to alternative forms of political activism, such as joining demonstrations, strikes or petitions is obviously lower than ten years ago (the third column of Table 3 indicates smaller percentages of citizens that would never engage in such activities). However, increased interest in political activities has mostly been directed to passive considerations of participating in such activities (might do), rather than active political involvement (have done). The indicators that capture true participatory political behavior imply a decreasing intensity of active political engagement. 
Table 2 Membership in political parties in Serbia (in \%)

\begin{tabular}{lrrrr}
\hline & \multicolumn{2}{c}{ Yes } & \multicolumn{2}{c}{ No } \\
& 2006 & 2016 & 2006 & 2016 \\
\hline Membership in a political party & 11,36 & 8,48 & 88,64 & 91,52 \\
\hline
\end{tabular}

Source: LiTS, 2006; 2016

Table 3 Forms of political activism in Serbia (in \%)

\begin{tabular}{lrrrrrr}
\hline & \multicolumn{3}{c}{ Have done } & \multicolumn{2}{c}{ Might do } & \multicolumn{2}{c}{ Would never do } \\
& 2006 & 2016 & 2006 & 2016 & 2006 & 2016 \\
\hline Demonstrations & 14,00 & 7,16 & 21,70 & 32,36 & 64,30 & 60,48 \\
Strike & 9,50 & 6,63 & 26,10 & 34,95 & 64,40 & 58,42 \\
Petitions & 12,91 & 11,60 & 42,74 & 44,63 & 44,34 & 43,77 \\
\hline \multicolumn{6}{c}{ Source: $2006 ; 2016$}
\end{tabular}

\section{RESULTS AND DISCUSSION}

For estimating the relevance of civic participation on the intensity of political involvement of citizens in Serbia, we employ the non-parametric analysis of variance test, Kruskal-Wallis $\mathrm{H}$ test. This procedure tests whether there are statistically significant differences between two or more groups of an independent variable, that is measured on an ordinal scale. The results of this analysis should imply whether the participation of citizens in different types of community organizations (independent variables) would affect citizens' decisions on membership in political parties or participating in various political activities, such as strikes, demonstrations, petitions (dependent variables). Since each type of community involvement is assumed to affect political participation in different ways, the analysis will be performed separately for each type. The data in our analysis meet the assumptions that underpin the Kruskal-Wallis procedure: the variables are measured on the ordinal scales, independent variables (involvement in different organizations) consist of three independent categorical groups (active member, inactive member, not a member), the observations are independent between and within the groups and the distributions of scores for groups of independent variable reflect the same variability.

Table 4 Kruskal-Wallis equality-of-populations rank test

\begin{tabular}{lccccccccc}
\hline & df & \multicolumn{2}{c}{ Membership } & \multicolumn{2}{c}{ Demonstrations } & \multicolumn{2}{c}{ Strikes } & \multicolumn{2}{c}{ Petitions } \\
& & $\chi^{2}$ & $\mathrm{p}>|\mathrm{t}|$ & $\chi^{2}$ & $\mathrm{p}>|\mathrm{t}|$ & $\chi^{2}$ & $\mathrm{p}>|\mathrm{t}|$ & $\chi^{2}$ & $\mathrm{p}>|\mathrm{t}|$ \\
\hline Religious & 2 & $20,09^{*}$ & 0,0001 & $29,58^{*}$ & 0.0001 & $20,92^{*}$ & 0.0001 & $6,59^{*}$ & 0,0371 \\
Sports & 2 & $26,73^{*}$ & 0,0001 & $76,72^{*}$ & 0.0001 & $78,46^{*}$ & 0.0001 & $46,40^{*}$ & 0.0001 \\
Art & 2 & $10,95^{*}$ & 0,0042 & $68,24^{*}$ & 0.0001 & $57,42^{*}$ & 0.0001 & $40,02^{*}$ & 0.0001 \\
Labour Union & 2 & $39,47^{*}$ & 0,0001 & $66,60^{*}$ & 0.0001 & $73,29^{*}$ & 0.0001 & $44,38^{*}$ & 0.0001 \\
Environmental & 2 & $20,77^{*}$ & 0,0001 & $26,35^{*}$ & 0.0001 & $17,63^{*}$ & 0.0001 & $9,54^{*}$ & 0.0085 \\
Professional & 2 & $24,30^{*}$ & 0,0001 & $62,20^{*}$ & 0.0001 & $59,02^{*}$ & 0.0001 & $53,00^{*}$ & 0.0001 \\
Humanitarian & 2 & $44,51^{*}$ & 0,0001 & $21,21^{*}$ & 0.0001 & $26,43^{*}$ & 0.0001 & $22,23^{*}$ & 0.0001 \\
Youth & 2 & 1,93 & 0,3810 & $34,78^{*}$ & 0.0001 & $17,88^{*}$ & 0.0001 & $7,67^{*}$ & 0.0216 \\
Women & 2 & $10,45^{*}$ & 0,0054 & $16,55^{*}$ & 0.0003 & $10,58^{*}$ & 0.0050 & $9,88^{*}$ & 0,0072 \\
Farmer & 2 & $15,04^{*}$ & 0,0005 & $14,80^{*}$ & 0.0006 & $11,66^{*}$ & 0.0029 & 5,13 & 0,0770 \\
\hline
\end{tabular}

Source: LiTS, 2016, author's calculations; *Significant at 5\% level 
Table 4 reports on the results of the test that determined if citizens' political involvement was different for three groups that either actively participated in a particular community organization (1), were passive members (2) or not members at all (3). The finding suggest that there are statistically significant differences in all forms of political participation, based on actors' involvement in organizations of civic society. The minor exceptions relate to participation in youth organizations not affecting party membership, while being a member of farmer cooperatives does not influence the political activity of signing petitions (obtained $\chi^{2}$ values, degrees of freedom and significance levels included in the output).

As the analysis performed only indicates that at least two groups within the civic participation variable differ from each other, we use post hoc test to determine which specific groups are significantly different in terms of political involvement. The results of pairwise comparisons of means, displayed in Table 5, indicate statistically significant differences at the $\mathrm{p}<0.05$ levels in alternative forms of political participation between particular groups of citizens with different levels of civic participation.

Considering party membership (with the assigned values yes -1 and no -2 ) as dependent on the involvement in a civic association, the findings are mostly conclusive groups of citizens that are not members of a particular organization tend to be less inclined to become members of a political party, compared to passive or active members. Minor exceptions are related to sports organizations, where the analysis determined that active sports members are less interested to be members of political parties than passive ones. Membership in youth organizations does not seem to be relevant for political involvement, as previously stated. Considering all other cases, the degree of activity in civic organizations encourages political activism in terms of party membership.

According to the findings, community engagement is a significant predictor of nonconventional political activities. The values assigned to the variables concerning attendance on demonstrations, strikes and signing petitions (have done -1 , might do -2 , would never do 3 ) are higher for the non-members compared to members. There are variations present when analyzing the relevance of being an active or passive member of an organization for political activism, that depend on a particular type of association. For example, active members of labor unions and professional organization tend to participate more actively in strikes, while for the majority of organizations, being active or passive member does not have an impact on political activity. In most situations, the membership itself is positively affecting political activism. In general, our analysis confirms the significance of membership in associations for political involvement in Serbia.

Such results are consistent with previous empirical findings about the relevance of participation in voluntary organizations for the level of political involvement in transition countries. A majority of studies have confirmed that people participating in larger social networks do express larger interest for politics (Knack, 1992; Rosenstone and Hansen, 2003). Letki (2004) confirms a large impact of community association membership on political involvement, although emphasizing that associations do vary in terms of their relevance for political involvement. In testing the determinants of both conventional and non-conventional political participation in Romania, Uslaner (2004) finds strong effects of active participation in civic organizations on participation in political life. The studies, however, indicate a wide range of other potential determinants of political participation that are beyond the scope of our analysis, such as social trust, socio-economic characteristics of citizens (income, education, age, gender), along with country level factors that reflect state of democracy and quality of political institutions. 
Table 5 Membership in political parties in Serbia (in \%)

\begin{tabular}{|c|c|c|c|c|c|c|c|c|c|}
\hline \multirow{2}{*}{\multicolumn{2}{|c|}{ 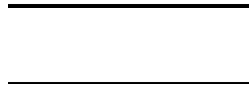 }} & \multicolumn{2}{|c|}{ Membership } & \multicolumn{2}{|c|}{ Demonstrations } & \multicolumn{2}{|c|}{ Strikes } & \multicolumn{2}{|c|}{ Petitions } \\
\hline & & Contrast & $\mathrm{p}>|\mathrm{t}|$ & Contrast & $p>|t|$ & Contrast & $\mathrm{p}>|\mathrm{t}|$ & Contrast & $p>|t|$ \\
\hline \multicolumn{10}{|l|}{ Religious } \\
\hline+ & 2 vs 1 & .010 & .752 & .227 & $.002 *$ & .188 & $.009^{*}$ & .091 & .246 \\
\hline & 3 vs 1 & .086 & $.001 *$ & .307 & $.000 *$ & .252 & $.000^{*}$ & .137 & $.034 *$ \\
\hline & 3 vs 2 & .076 & $.000^{*}$ & .081 & .093 & .064 & .178 & .046 & .374 \\
\hline \multicolumn{10}{|l|}{ Sports } \\
\hline & $2 v s 1$ & -.135 & $.005^{*}$ & -.081 & .432 & -.051 & .619 & -.085 & .445 \\
\hline & 3 vs 1 & .008 & .846 & .385 & $.000 *$ & .409 & $.000^{*}$ & .302 & $.001 *$ \\
\hline & $3 v s 2$ & .142 & $.000 *$ & .466 & $.000 *$ & .460 & $.000^{*}$ & .387 & $.000 *$ \\
\hline \multicolumn{10}{|l|}{ Art } \\
\hline & $2 v s 1$ & .005 & .940 & -.237 & .073 & -.240 & .067 & -.037 & .797 \\
\hline & 3 vs 1 & .100 & .059 & .375 & $.001 *$ & .324 & $.003^{*}$ & .415 & $.001 *$ \\
\hline & 3 vs 2 & .095 & $.005 *$ & .612 & $.000 *$ & .564 & $.000^{*}$ & .452 & $.000^{*}$ \\
\hline \multicolumn{10}{|c|}{ Labour Union } \\
\hline & $2 v s 1$ & .036 & .546 & -.192 & .135 & .376 & $.003^{*}$ & -.144 & .299 \\
\hline & 3 vs 1 & .189 & $.000 *$ & .298 & $.010^{*}$ & .144 & .205 & .289 & $.020 *$ \\
\hline & 3 vs 2 & .153 & $.000^{*}$ & .490 & $.000 *$ & .520 & $.000^{*}$ & .433 & $.000^{*}$ \\
\hline \multicolumn{10}{|c|}{ Environmental } \\
\hline & $2 v s 1$ & .049 & .657 & -.004 & .985 & .065 & .780 & -.073 & .772 \\
\hline & 3 vs 1 & .208 & $.048 *$ & .427 & .052 & .408 & .061 & .209 & .380 \\
\hline & 3 vs 2 & .158 & $.000 *$ & .431 & $.000 *$ & .344 & $.000^{*}$ & .282 & $.002 *$ \\
\hline \multicolumn{10}{|c|}{ Professional } \\
\hline & $2 v s 1$ & .130 & $.023^{*}$ & .301 & $.016^{*}$ & .301 & $.015^{*}$ & .184 & .174 \\
\hline & 3 vs 1 & .206 & $.000 *$ & .723 & $.000 *$ & .706 & $.000^{*}$ & .639 & $.000 *$ \\
\hline & $3 v s 2$ & .076 & $.038 *$ & .421 & $.000 *$ & .405 & $.000^{*}$ & .455 & $.000 *$ \\
\hline \multicolumn{10}{|c|}{ Humanitarian } \\
\hline & $2 v s 1$ & .047 & .518 & -.156 & .340 & -.033 & .837 & -.027 & .878 \\
\hline & 3 vs 1 & .223 & $.001 *$ & .142 & .352 & .307 & $.040^{*}$ & .285 & .080 \\
\hline & $3 v s 2$ & .176 & $.000 *$ & .298 & $.000 *$ & .340 & $.000^{*}$ & .312 & $.000 *$ \\
\hline \multicolumn{10}{|l|}{ Youth } \\
\hline & $2 v s 1$ & -.133 & .175 & .248 & .256 & .291 & .180 & -.058 & .807 \\
\hline & 3 vs 1 & -.084 & .317 & .730 & $.000 *$ & .620 & $.001 *$ & .238 & .240 \\
\hline & $3 v s 2$ & .048 & .342 & .481 & $.000 *$ & .329 & $.004 *$ & .296 & $.017^{*}$ \\
\hline \multicolumn{10}{|l|}{ Women } \\
\hline & 2 vs 1 & -.125 & .203 & -.350 & .113 & -.300 & .169 & -.300 & .205 \\
\hline & 3 vs 1 & .019 & .827 & .044 & .824 & .027 & .891 & .031 & .886 \\
\hline & 3 vs 2 & .144 & $.001 *$ & .393 & $.000 *$ & .327 & $.001 *$ & .331 & $.001 *$ \\
\hline \multicolumn{10}{|l|}{ Farmer } \\
\hline & $\begin{array}{l}2 v s 1 \\
3 v s 1\end{array}$ & $\begin{array}{l}.133 \\
.253\end{array}$ & .1000 & $\begin{array}{l}.341 \\
.627\end{array}$ & $.001 *$ & $\begin{array}{l}-.005 \\
.362\end{array}$ & $.043 *$ & $\begin{array}{l}-.102 \\
.162\end{array}$ & $\begin{array}{l}.634 \\
.406\end{array}$ \\
\hline & $3 v s 2$ & .120 & $.019^{*}$ & .286 & $.012 *$ & .367 & $.001 *$ & .264 & .077 \\
\hline
\end{tabular}




\section{CONCLUSION}

The paper deals with the issues of civic and political participation, with a special focus on the post transition period in the countries that have transformed their economic and political systems, usually referred to as new democracies. Our analysis tends to contribute to the existing literature by empirically investigating the relevance of the involvement in civic associations for the citizens' political participation in Serbia. Contrary to the assumptions of civic demobilization in transition countries, our findings indicate that proportions of citizens engaged in various types of community organizations have steadily grown over the last decade. However, the dynamics of civic participation reveals that the increase has been largely limited to the passive forms of participation. Furthermore, compared to established democracies, the degree of associational activity in Serbia is rather low. The patterns of political participation, especially the non-conventional forms of political activism, seem to follow the dynamics of civic participation. The employed empirical procedures confirm the assumptions that associational activity is a significant predictor of all types of political engagement, which is in line with prior empirical investigations on the relation between civic and political participation in both developed and transition countries.

The obtained empirical findings are to be interpreted bearing in mind the usual methodological limitations related to the usage of survey data on subjective preferences and attitudes. Further research should focus on exploring a wider set of determinants that affect the levels of political participation in countries that are still going through the democratic consolidation process. Such studies provide useful implications for the policies aimed at strengthening civic society and creating incentives for citizens' active involvement in political life as an essential element of credibility of institutions.

Acknowledgement: The paper is a part of the research done within the project 179066. The authors would like to thank to the Ministry of Education, Science and Technological Development for funding.

\section{REFERENCES}

Adler, R. P. \& Goggin, J. (2005). What Do We Mean By “Civic Engagement”? Journal of Transformative Education, $3(3), 236-253$.

Almond, G. A. \& Verba, S. (1963). The Civic Culture. Political Attitudes and Democracy in Five Nations. Princeton: Princeton University Press.

Bădescu, G. \& Radu, B. (2010). Explaining Political Participation in East Central Europe. In Halman, L \& Voicu, M. (Eds.), Mapping value orientations in Central and Eastern Europe (pp. 169-194). Leiden: Brill Academic Publishers.

Berger, B. (2009). Political Theory, Political Science, and the End of Civic Engagement. Perspectives on Politics, 7 (2), 335-350.

Durkheim, E. (1984 [1893]). The Division of Labour in Society. London: Macmillan.

EBRD (2016). Life in Transition: A Decade of Measuring Transition. London: EBRD.

Ekiert, G. \& Foa, R. (2011). Civil Society Weakness in Post-Communist Europe: A Preliminary Assessment. Carlo Alberto Notebooks, No. 198. Torino: Collegio Carlo Alberto.

Ely, J. (1994). Libertarian Ecology and Civil Society. Society and Nature, 2 (3), 98-151.

Howard, M. M. (2002). Post-communist civil society in comparative perspective. Demokratizatsiya, 10 (3), 285-305.

Howard, M. M. (2003). The Weakness of Civil Society in Post-Communist Europe. Cambridge, Cambridge University Press. 
Inglehart, R. (1999). Trust, well-being and democracy. In: Warren M. E. (Ed.), Democracy and trust. Cambridge: Cambridge University Press.

Kaase, M. \& Newton, K. (Eds.) (1995). Beliefs in Government. Oxford: Oxford University Press.

Kaase, M. \& Marsh, A. (1979). Political Action. A Theoretical Perspective. In: Barnes, S. \& Kaase, M. (Eds.), Political Action: Mass Participation in Five Western Democracies (pp. 27-56). London: Sage.

Knack, S. (1992). Civic Norms, Social Sanctions, and Voter Turnout. Rationality and Society, 4, 133-156.

Kruskal, W. H. \& Wallis, W. A. (1952). Use of Ranks in One-Criterion Variance Analysis. Journal of the American Statistical Association, 47 (260), 583-621.

Letki, N. (2004). Socialization for Participation? Trust, Membership, and Democratization in East-Central Europe. Political Research Quarterly, 57 (4), 655-679.

LiTS (2016), Life in Transition Survey III: A decade of measuring transition, database. Retrieved from: http://www.ebrd.com/what-we-do/economic-research-and-data/data/lits.html, Accessed on: 01 October 2017.

LiTS (2010), Life in Transition Survey II: After the crisis, database. Retrieved from: http://www.ebrd.com/whatwe-do/economic-research-and-data/data/lits.html, Accessed on: 01 October 2017.

LiTS (2006), Life in Transition Survey I: A survey of people's experiences and attitudes, database. Retrieved from: http://www.ebrd.com/what-we-do/economic-research-and-data/data/lits.html, Accessed on: 01 October 2017.

Lomax, B. (1997). The Strange Death of Civil Society in Post-Communist Hungary. Journal of Communist Studies and Transition Politics, 13 (1), 41-63.

Milbrath, L. \& Goel, M. (1977). Political Participation: How and Why Do People Get Involved in Politics? Boston: Rand McNally College Publishing Company.

Minkenberg, M. (2002). The Radical Right in Post-Socialist Central and Eastern Europe: Comparative Observations and Interpretations. East European Politics and Societies, 16 (2), 335-362.

Newton, K., \& Norris, P. (2000). Confidence in public institutions: Faith, culture or performance? In: Pharr, S. J. \& Putnam, R. D. (Eds.), Disaffected democracies: What's troubling the trilateral democracies? (pp. 5273). Princeton: Princeton University Press.

Norris, P. (2002). Democratic Phoenix. Reinventing Political Activism. Cambridge: Cambridge University Press.

Norris, P. (Ed.) (1999). Critical citizens: Global support for democratic governance. Oxford: Oxford University Press.

Ostrom, E. (1990). Governing the Commons. The Evolution of Institutions for Collective Action. Cambridge: Cambridge University Press.

Petričušić, A. (2013). Democracy without Citizens: Inadequate Consolidation in Two Decades of Western Balkans Democracy. European Quarterly of Political Attitudes and Mentalities, 2(4), 34-54.

Putnam R.D., Leonardi, R. \& Nanetti, R. (1993). Making Democracy Work: Civic Traditions in Modern Italy. Princeton: Princeton University Press.

Putnam, R. (1995). Bowling Alone: America's Declining Social Capital. Jornal of Democracy, 6 (1), 65-78.

Putnam, R. (2000). Bowling Alone. The collapse and revival of American community. New York: Simon and Schuster.

Rose, R. (2009). Understanding Post-Communist Transformation. A bottom up approach. London/NY: Routledge.

Rose-Ackerman, S. (2001). Trust, Honesty, and Corruption: Reflection on the State-Building Process. European Journal of Sociology, 42 (3), 27-71.

Rosenstone, S. J. \& Hansen, J. M. (2003). Mobilization, Participation, and Democracy in America. New York: Macmillan.

Rupnik, J. (2007). From Democratic Fatigue to Populist Backlash. Journal of Democracy, 18, (4), 17-25.

Sartori, G. (1970). Concept Misformation in Comparative Politics. American Political Science Review, 64 (4), 1033-1053.

Skocpol, T. \& Fiorina, M. P. (Eds.) (1999). Civic Engagement in American Democracy. Washington: Brookings Institution Press.

Stolle, D. \& Hooghe, M. (2005). Inaccurate, Exceptional, One-Sided or Irrelevant? The Debate about the Alleged Decline of Social Capital and Civic Engagement in Western Societies. British Journal of Political Science, 35 (1), 149-167.

Tocqueville, A. (1835, 1840 [1990]). Democracy in America. Reprint, New York: Vintage.

Uslaner, E. M. (2004). Bowling Almost Alone: Political Participation in a New Democracy. Paper prepared for presentation at the ECPR Joint Sessions of Workshops: Emerging Repertoires of Political Action: Toward a Systematic Study of Post-conventional Forms of Participation, Uppsala, Sweden, April 13-18, 2004.

Uslaner, E.M. (2005). Civic Engagement in America: Why People Participate in Political and Social Life. University of Maryland-College Park: Department of Government and Politics.

Verba, S., Schlozman, K. L. \& Brady, H. E. (1995). Voice and Equality. Civic Voluntarism in American Politics. Cambridge: Harvard University Press.

Wallace C., Pichler F. \& Haerpfer, C. (2012). Changing Patterns of Civil Society in Europe and America 19952005. Is Eastern Europe Different? East European Politics and Societies, 26 (1), 3-19.

Wuthnow, R. (1998). Loose connections: Joining together in America's fragmented communities. Cambridge: Harvard University Press. 


\section{GRAĐANSKA I POLITIČKA PARTICIPACIJA U TRANZICIONIM ZEMLJAMA: SLUČAJ SRBIJE}

Cilj rada je da istraži dinamiku građanske participacije u Srbiji, kao i da ispita njen uitcaj na političko angažovanje građana Srbije. Za ispitivanje uticaja članstva u građanskim udruženjima na članstvo u političkim partijama $i$ nekonvencionalne oblike političkog aktivizma, primenjen je neparametarski test analize varijanse $i$ post hoc test. Glavni nalazi istraživanja ukazuju da građanska participacija predstavlja značajan faktor političkog aktivizma građana Srbije. Rezultati empirijskih analiza ukazuju na značajne razlike u stepenu političke participacije, koje su zasnovane na razlikama u stepenu građanskog angažovanja u društvenim organizacijama. Implikacije ovog istraživanja mogu da predstavljaju osnov za kreiranje politika usmerenih ka jačanju građanskog društva i stvaranje podsticaja za aktivno učešće građana u političkom životu.

Ključne reči: građansko društvo, politička participacija, tranzicija, demokratija 